\title{
TOWARD THE BEST MODEL IN RECRUITMENT PROCESS AND EMPLOYEE COMPETENCE IN OUTSOURCING INDUSTRIES
}

\author{
Mochamad Soelton and Fakhru Ahdiansyah \\ Universitas Mercu Buana \\ Email: soelton@mercubuana.co.id
}

\begin{abstract}
This study aims to examine and analyze the effect of the recruitment process, selection process and employee competence on outsourced employee performance( in outsourcing Industries). Data was collected through questionnaires distributed and executed on 70 employees of outsourcing of commercial division, data analysis in this research using non- probability sampling technique and using saturation sampling where its data processing using Statistical Package for Social Science (SPSS) version 23 program. The results of the analysis show that the Recruitment Process, Selection process and Competence have the positive and significant impact on Employee Performance.
\end{abstract}

Keywords: Recruitment Process, Selection Process, Competence and Employee Performance

\section{BACKGROUND}

Company expects to have quality assets, one of the most important assets that expected is employees. Employees can be said to be the most important asset because employees of life assets that can help advance in achieving the objectives expected by Hasibuan (2014). Company or an organization firmly believes that success in obtaining human resources begins with accuracy in the recruitment process. Therefore, it is important to continue recruit talented people who have the ability and potential to contribute to long-term business growth. Kurniasih and Heliantono (2016) assert that according to Barney's theory (1991) that an organization can succeed if it can achieve and maintain its competitive advantage. The success can be achieved if the company allocates what competitors do not have, and the efficient and effective use of resources is a driver for achieving competitive advantage and improving company performance.

Recruitment process is viral within a company. Accuracy in recruitment can enhance the effectiveness and efficiency of operations of the company. In addition, a good recruitment process can also affect the productivity of a company (Pranoto, 2016). Good management can help companies to get the right employee and in accordance with the needs of the company. So to get a quality employee then every company must have the recruiting system and running the right prospective employees.

The main focus of human resources management (MSDM) was contributed to the success of the company. In order to be the productivity of companies running smoothly required manpower or the employees in accordance with the principle of "the right man in the right place" according to Henry (2010). Then the task of the Department of human resources (HR) is to fill the post with a suitable and qualified human resource for the job through a recruitment process. The implementation of recruitment and selection is a very important task, crucial and needed a big responsibility. 
Tabel 1.1

Jumlah Karyawan PT. Brilliant Ecommerce Berjaya Per April 2017

\begin{tabular}{lcccc}
\hline \multicolumn{1}{c}{ Divisi } & $\begin{array}{c}\text { Karyawan } \\
\text { Tetap }\end{array}$ & $\begin{array}{c}\text { Karyawan } \\
\text { Kontrak }\end{array}$ & $\begin{array}{c}\text { Karyawan } \\
\text { Outsourcing }\end{array}$ & Total \\
\hline BOD & 3 & 0 & 0 & 3 \\
Commercial & 6 & 2 & 70 & 78 \\
Marketing & 6 & 1 & 2 & 9 \\
BIDS \& RM & 6 & 2 & 2 & 10 \\
Vendor Acquisition & 15 & 4 & 1 & 20 \\
Vendor Management & 15 & 6 & 7 & 28 \\
Finance, Accounting and & 17 & 4 & 5 & 26 \\
Tax (FAT) & 6 & 2 & 1 & 9 \\
Legal and Compliance & 5 & 2 & 1 & 8 \\
HRGA & 10 & 2 & 6 & 18 \\
Tech & 21 & 0 & 7 & 28 \\
Product & 15 & 0 & 8 & 23 \\
Warehouse & 125 & 25 & 110 & 260 \\
\hline \hline Total & \multicolumn{2}{c}{ Silliant Ecommerce Berjaya } \\
Sumber: Head Human Resource PT. Brill
\end{tabular}

In Table 1 can be seen on the overall Division, only commercial division has the most employees outsourcing percentage, with the composition of the $8 \%$ of employees with permanent status, $3 \%$ of employees with the status of the contract, and $90 \%$ of employees with the status of outsourcing, It is usually caused by not having the ability of work in accordance with the qualification of its work so that it can be a significant problem, which interferes with the process of achievement of vision and business goals of the company so that at the time of the assessment the employee, the employee is not yet graduated to become a clerk not fixed/contract or become permanent employees.

The Recruitment process that has done Successful starts with how to analyze the needs of human resources, after having analyzed the problem of the company in need of some employees who are experienced in their field, After that specifies the terms of what is required in filling the job, such as an Associate understand how to respond to a package of customer also create PO, an Operation capable of reviewing a letter of cooperation agreement between the company and the customer as well as being able to create a sales invoice and request a tax receipt in accordance with the terms of the terms required by the team FAT, an Operation Support was able to follow up costumer goods documents and deal with customer orders customer complaints, a Collection shall able to handle customer payment billing documents the completeness of other needs in the Commercial team. After the company describes the terms of what is required in the filling of the work, the company began to publish it through employee Mbiz itself by email your jobs to all employees. And advertising in conventional media and online, as well as identify the graduates of potential schools and universities through the recruitment activities of the campus. After publishing, Mbiz is waiting for an application that goes in to the company. Applications that enter any selection by HRD in order for applicants to be accepted in accordance with the needs of the company.

In addition to recruitment processes, Mbiz doing selection of employees as one strategy that has done. According to Veithzal Rivai (2008) that: "the selection process is a series of events that are used to decide whether the applicants are accepted or rejected". Any employee selection is just as important in increasing the performance of employees. This is in accordance with the opinion of the Veithzal Rivai (2008) "the selection process 
in accordance with the principles human resource management will result in the selection of employees can be expected in the future to contribute a positive and good ".

Selection process that has been done by Mbiz collected will then be selected from the existing cover letter which best suits the needs of the company, then applicants will be contacted to perform various tests such as tests of ability/ skills, academic potential tests, health tests and personality tests. After done tests then conducted the interviews, after interviewing prospective employees will then wait for a decision whether accepted or rejected, as for the composition of candidates accepted employee will be seen again competencies are prospective employees the viable became an employee stays with the probation period of 3 months or by contract employees be Mbiz, or prospective employees will follow the stages of the recruitment outsourcing. Mbiz cooperates with the service company engaged in the outsourcing mechanism whereby prospective employees who already escaped in the criteria of recruitment and selection stage but there is still some consideration from the competence of prospective employees so prospective employees will be offered by a recruitment process outsourcing. Soelton and Mahdalena (2018), Performance is the result of work in quality and quantity achieved by an employee in performing his duties in accordance with the responsibilities give to him.

\section{LITERATURE REVIEW}

Employee Performance. While the performance according to Wirawan (2015), the output is generated by functions or indicators of an occupation or a profession within a specified time. Factors which affected it can generally be grouped into three types, namely: work, work behavior, and personal traits that are associated with the job. Hapsi Ali et al. (2017) reveals that innovation is the ability to turn ideas into goods, processes or processes to solve problems and take advantage of the opportunities it faces. Innovation is a process by which the organization uses its capabilities and resources to develop new products or new system procedures. Innovations such as the need to take and learn together among members of community learning organizations.

According to Soedjono (2005) there are six criteria for measuring the performance of individual employees, namely: (1) Quality, the results of the work performed is approaching perfection; (2) Quantity, the amount that is generated or the number of activities that can be completed; (3) Timeliness can be completed on time and can maximize the time available for other activities; (4) Effectiveness, maximum utilization of the existing resources of the Organization to increase profits and reduce losses; (5) Independence can carry out work without assistance in order to avoid the adverse results; (6) Work Commitment, the commitment of work between employees with the organization.

Dimensions Of employee Performance. According to Wirawan (2015) in general dimensions of performance can be grouped into three types, namely: (1) Results of the Work; (2) Work Behavior; (3) Personal nature which related to the job

Recruitment Process. Recruitment is "effort seek and affect the manpower, to apply for jobs that exist in a company" Hasibuan (2014) while "Recruitment is the process of searching and" decoy "the prospective employees (applicants) are able to apply as an employee "(Handoko, 2012). To get qualified prospective employees, then the company should be able to do a good recruitment process. The company must be able to identify the 
needs of its employees. In addition, the company must also be able to determine the basis of recruitment, recruitment sources, sources of recruitment methods used and identify the constraints of recruitment.

This recruitment process is the process of searching for, find, engage and set a number of people from within and from outside the company as a Labor candidate with certain characteristics that have been defined in the planning of human resources. The results obtained from the process of recruitment is a number of workforce that will enter the selection process, i.e. a process to determine which candidate was most qualified to fill the position of certain companies available at, after the held HR planning, and analysis as well as the classification of occupations (Setiani, 2013).

The Dimensions of The Recruitment Process. Employee recruitment activities there are a few things that became the basic concept to note both before and after the recruitment activity for human resources that have certain specifications that comply with the duties and the job responsibilities will be addressed.

1. Internal resources: (a) Promotion; (b) Demotion

2. External resources: (a) Labor placement Office; (b) Educational institutions; (c) Employee References; (d) Job training programs; (e) Department of labor

Selection Process. Selection is the series of activities has been done by the company/organization to be able to take decisions about anybody from prospective employees/employees who are most appropriate (qualified) to be accepted into an employee/employees and anyone which should be rejected for being accepted into officers/employees. In other words, through the selection of organizations/companies will be classified prospective employees into two classifications, i.e. they are rejected and they received (Gaol, 2015).

Selection of employees is said to be effective has three objectives: fairness, accuracy, and confidence. Accuracy, it means the ability of a selection process to appropriately can predict the performance of applicants. The following questions may be taken into consideration when making the selection, such as what the disadvantages of: (1) Instructors, who are less over matter?; (2) Selection process which could not predict the performance of the applicants in the workplace?; (3) Calculation by using a computer that produces the wrong answer.

Justice means giving warranties that any applicants who meet the requirements are given the same opportunity in the system selection. Fair selection system, when: (1) Based on requirements that run consistently. Using the same standards of acceptance for all applicants; (2) Filter applicants based on considerations that are only related to employment only.

Confidence level, meaning that people who are involved in the selection process for certain of the benefits derived. The interviewer or the test giver believes will be a system of selection if: (1) During selection processes conducted, applicants and interviewers use the time effectively; (2) Everyone benefits by following the selection process regardless of the employee's receipt of the decision taken; (3) Corporate image and self-esteem applicants stay awake.

The Dimensions Of The Selection Process. According to Mondy and Noe (2010). A good selection of must-have features, among others: 
1) Standardization. A good test must have uniformity the procedures conditions for all participants. In conveying from multiple applications in the same test.

1) Objectivity. For every same answer must be given the same results/value. The results and the value of the test should not be based on subjectivity against certain aspects of the process of the test.

2) Norm. Each test must have norms, i.e., the frame of reference to compare the achievements of the applicants. Without norm, results of participants cannot be classified whether the value is good or bad.

1) Reliability. Reliability means that a selection tool delivers consistent results every time people attended the test.

2) Validity. The selection is associated significantly with performance or other relevant criteria. In other words, a test is said to be valid if the test actually measures what it wants to be measured.

Competency. Moeheriono (2012) stated that competence is the underlying characteristics of the person related to the effectiveness of individual performance in his job or the basic characteristics of individuals who have causal relationships or causal as the criteria made reference, effective or superior or excellent performance at work or in certain situations.

Sutrisno (2010) suggests the concept of competence is becoming increasingly popular and has been widely used by big companies for various reasons, including:

1) Clarify the standard of work and hope to achieve in this competency model will be able to answer two fundamental questions: skills, knowledge, and what are the characteristics of the performance. Both of these will help a lot in reducing the decision-making in the field of subjectively human resources.

2) Use of employee selection Tools competency standards as tool selection can help organizations to choose good prospective employees. With clarity against the effective behavior is expected of employees, we can drive on target that selective as well as reduce the cost of recruitment. How to develop something with behavior that is required for each function of the Office as well as focusing on the behavior selection interview is sought.

3) Maximize Productivity Demands to make a lean organization requires us to find employees that could be developed are directional to close gaps in skills, so being able to mobilize vertically or horizontally.

4) The basis for the development of the system of remuneration of the competency Model can be used to develop a system of remuneration (rewards) that would be considered more fair. Remuneration policy will be more targeted and transparent with hooking as many decisions with a set of expected behavior shown of an employee.

5) Facilitate the adaptation to change in an era of rapid change, the nature of a job very quickly changed and the need for new capabilities continue to increase. Competency models provide a means to define what skills are needed to meet the ever-changing needs.

6) Align the behavior of work with the Organization's values competency Model is the easiest way to communicate the values and things what should be focused on employee performance.

Dimensions of Competence. Competence has characteristics that are attached to the individual. It's competence that is inherent in the individual as the motivation, attitudes, knowledge, and others. The characteristics of competency according to Sutrisno (2010) 
there are five aspects, namely: (a) Motives; (b) Traits; (c) Self-concept; (d) Knowledge; (d) Skill

Theoretical Model: (1) Do recruitment process affect to employee performance?; (2) Do selection process affect to employee performance?; (3) Do competence affect to employee performance?

Based on literature review and previous research then the research formulates the framework of thought as follows:

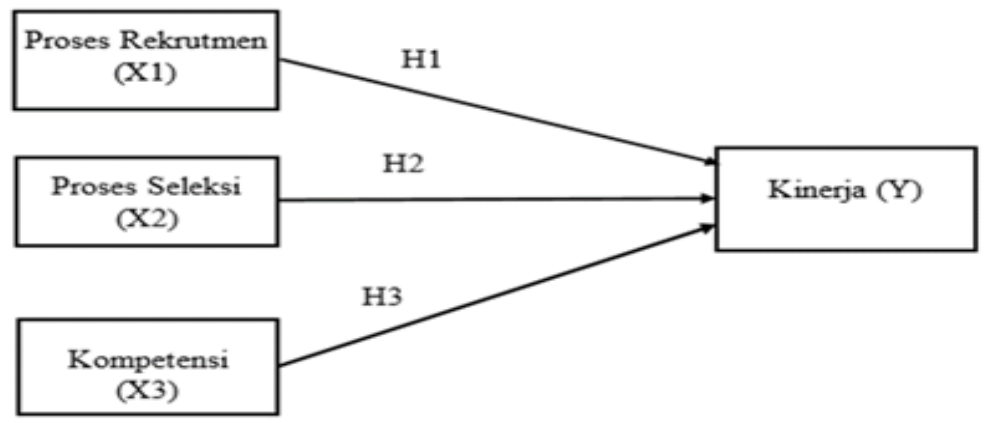

GAMBAR 2.1 RERANGKA KONSEPTUAL PENELITLAN

Research Objective. The goal will be achieved by this research is to know the effect of the recruitment process, to know how the selection process, and to know the effect of the competency to the employee performance.

\section{METHOD}

The research process begins with identifying the problems in the place to be used as the research location, formulation of identified problems, the collection of basic theories that strengthen the foundations in the variables, the preparation of methods in data collection, the preparation of instruments, to the determination of statistical testing techniques used. In this research, the authors used a quantitative descriptive analysis, data analysis methods used that is a research design of causal research for analyzing the relationships between one variable with other variables or how a variable affects other variables. The population in this research is at the office of PT Brilliant Ecommerce Berjaya, Period July - December 2017. Determination of the sample used in this study using a type of saturated sampling technique. The term saturated sample is a census, where all members of the population are sampled. The design of analyzing utilized in this research using Multiple Linear Regression Analysis aims to see the effect of two independent variables with one dependent variable. The statistical approach for this is through multiple linear regression analysis that is useful for determining the magnitude of the influence of two or more variables at the same time looking at the level of influence. This method is also commonly used to predict or predict the value of a variable between more than one predictor variable (independent variable) to the dependent variable.

\section{RESULTS AND DISCUSSION}


Coefficient Determination Test (R2) and the correlation. Coefficient determination is used to find out how big the free variables have the effect on dependent variable. The value of the coefficient of determination used adjusted $\mathrm{R}$ square.

Table 2. Uji Koefisien Determinasi $\left(\mathrm{R}^{2}\right)$

Model Summary ${ }^{b}$

\begin{tabular}{ccccc}
\hline Model & R & R Square & $\begin{array}{c}\text { Adjusted R } \\
\text { Square }\end{array}$ & $\begin{array}{c}\text { Std. Error of } \\
\text { the Estimate }\end{array}$ \\
\hline 1 &, $908^{\mathrm{a}}$ &, 824 &, 816 & 1,9480 \\
\hline
\end{tabular}

a. Predictors: (Constant), Competence, Recruitment, Selection

b. Dependent Variable: Performance

Based on Table 2 above, the results of the coefficient determination (R2 adjusted) very strong of 0.816 it means $81.6 \%$ the employee Performance can be explained by variable recruitment process, selection process, and Competency. While the rest $18.4 \%$ is explained by other variables that are not included in this research model.

Simultaneous Significance Tests (F Test). Statistical tests show whether F is all independent variables referred to in the model have the influence of the dependent variables against simultaneously. By comparing the probability (in Anova table writing $\mathrm{Sig})$ and extent of fact (0.05 or 0.01).If the probability of significance bigger than $0.05 \mathrm{Ha}$ rejected Ho accepted and if the probability of significance less than 0.05 HaacceptedHo rejected. Based on the above Table 4.18, obtained the following information:

a. $\mathrm{F}$ value $103.155>\mathrm{F}$ Table $(\mathrm{df} 1, \mathrm{df} 2,4-1=3,70-4=66$, pronounced $=5 \%$ ) amounting to 2.75. Then Ho rejected and Ha accepted.

b. The sig value $0.000<0.05$ so, the simultaneously independent variable effect significantly to the dependent variable.

Significant Partial Test results (T test). Statistic $\mathrm{T}$ test shows how far the effect of explanatory variables/independent one individually in the dependent variable explained variation., namely:

1) If the probability/significance $>0.05$ then Ho accepted and Ha rejected

2) If the probability/significance $<0.05$ then Ho rejected and Ha accepted.

Decision making is also done by comparing T-Tabel with T-Hitung with significant levels of provision of (a) a $5 \%$ error rate $(5 \%$ or 0.05 or $95 \%$ confidence level or 0.95 can use the formula:

$$
\mathrm{df}=\mathrm{n}-\mathrm{k}
$$

Where: n: number of observations/samples Shaper regression; k: number of variables (free + bound)

Tabel 3. Hasil Uji Signifikan Parsial (Uji T)

Coefficients $^{\mathrm{a}}$

\begin{tabular}{|c|c|c|c|c|c|}
\hline \multirow[t]{2}{*}{ Model } & \multicolumn{2}{|c|}{$\begin{array}{c}\text { Unstandardize } \\
\text { Coefficients }\end{array}$} & \multirow{2}{*}{$\begin{array}{c}\begin{array}{c}\text { Standardized } \\
\text { Coefficients }\end{array} \\
\text { Beta } \\
\end{array}$} & \multirow[t]{2}{*}{$\mathrm{t}$} & \multirow[t]{2}{*}{ Sig. } \\
\hline & $\mathrm{B}$ & Std. Error & & & \\
\hline (Constant) & 2,130 & 2,936 & &, 725 & ,471 \\
\hline
\end{tabular}




\begin{tabular}{lrrrrr}
\hline Recruitment &, 215 &, 078 &, 157 & 2,773 &, 007 \\
Selection &, 161 &, 057 &, 181 & 2,808 &, 007 \\
Competence &, 506 &, 042 &, 736 & 12,090 &, 000 \\
\hline
\end{tabular}

a. Dependent Variable: Performance

a. Hypothesis Test The effect of the recruitment process on the performance of employees

Based on Table 1.3 can be seen the value of $t$-value variable recruitment processes was 2.773 bigger than t-Table 1.996 and significant value from variable recruitment processes 0.007 smaller than 0.05 so Ho rejected and $\mathrm{Ha}$ accepted then it can be stated partially Recruitment Process has positive effect and significant to the employees performance.

b. Hypothesis Test The effect of the selection process on the employee performance

Based on Table 1.3 can be seen the value of t-value variable selection process was 2.808 bigger than t-table 1.996 and significant value of the variable selection process 0.007 smaller than 0.05 so Ho rejected and Ha accepted, then it can be stated partially selection process has positive effect and significant to the employees performance.

c. Hypothesis Test The effect of Competency on the employee performance.

Based on table 1.3 can be seen the value of $t$-value variable Competence is 12.090 bigger than t-Table 1.996 and significant value of 0.000 Competency variables smaller than 0.05 so Ho rejected and $\mathrm{Ha}$ accepted then it can be stated partially Competency has positive effect and significant to the employees performance.

\section{DISCUSSION RESULTS}

Influence On Performance Of The Employee Recruitment Process. Based on the test results the first hypothesis suggests that a positive and significant effect of recruitment on the employees performance. The results of this hypothesis were reinforced also by research from Billy Renaldo Potale (2016) that indicates that the recruitment process a positive and significant effect on the performance of employees. On the research of this recruitment process has a value of t-value is bigger than t-Table 2.773 1.996, hypothesized that we receive is the Ha1, so it can be inferred that the Recruitment Process variables (X1) have a positive and significant influence towards on performance Employees commercial Division.

The Influence Of The Selection Process On Performance Of Employees. Based on the results of the second hypothesis testing that shows that the selection process a positive and significant effect on the performance of employees. The results of this hypothesis were reinforced also by studies of Nurjanah Savitri, (2013) which indicates that the competence of the positive and significant effect on the performance of employees. On the research of this selection process has a value of t-value is bigger than t-Table 2.808 1.966, hypothesized that we receive is $\mathrm{Ha} 2$, thus it can be concluded that the selection process for the variables (X2) has a positive and significant influence on performance Employees commercial.

The Influence On Performance Competence Of Employees. Based on the results of the third hypothesis testing that shows that a positive and significant effect of competence against the performance of employees. The results of this hypothesis were reinforced also 
by studies of Nindrijo Sunu Pambagio, Hamida Nayati Utami, Gunawan, (2013) which indicates that the competence have positive and significant effect on the performance of employees. On the research of this Competence has a value of t-value is bigger than $t-$ Table 12.090 1.966, hypothesized that we receive is Ha3, so it can be concluded that the Competence variables (X3) has a positive and significant influence on performance Employees commercial Division.

\section{CONCLUSION}

1) The recruitment process a positive and significant effect on the performance of employees outsourcing.

2) A selection process a positive and significant effect on the performance of employees outsourcing.

3) The competence of a positive and significant effect on the performance of employees outsourcing.

Recommendation. The company must pay more attention to employee recruitment process that comes from employment agencies in order to get prospective employees that comply with the criteria required by the company to have a good work qualification, as well as the company able to contribute to the employee with the promotion.

The company should pay attention to the overall selection process employees are effective against some of the test time limit receipt of prospective employees. The company also was able to deceive the Test tools such as the computer always functioning properly.

Some of the results of the study also showed that the level of competence of employees outsourcing Division Commercial i.e. lack of managerial skills both in terms of the completion of all the types of jobs that have been granted and should be more pay attention to the application of the appropriate employee with competencies in which each employee-owned can solve or handle the job.

\section{REFERENCES}

Ambar, Teguh, Sulistiyani. (2011). Manajemen Sumber Daya Manusia. Yogyakarta: Graha Ilmu

Dwi, Priyatno. (2012). Teknik Mudah dan Cepat Melakukan Analisis Data Penelitian dengan SPSS dan Tanya Jawab Ujian Pendadaran. Badan Penerbit, Yogyakarta: Gaya Media.

Edy, Sutrisno. (2012). Manajemen Sumber Daya Manusia. Jakarta: Kencana.

Gaol, CHR, Jimmy. (2015). A to Z Human Capital-Manajemen Sumber Daya Manusia. Jakarta: PT. Gramedia Widiasarana Indonesia.

Ghozali, Imam (2013). Aplikasi Analisis Multivariate dengan program SPSS. Semarang: Badan penerbit Universitas Diponegoro.

Handoko TH,. (2012). Manajemen Dalam Berbagai Perspektif. Jakarta: Erlangga

Hapsi, Ali, Mukhtar, Risnita \& Muspawi, Mohamad. (2017). "Influence of Transformational Leadership and Cultural Organization toward Chairman Innovation of Stai: The College of Islamic Religion of Private in Jambi Province”. Internasional Journal of Business and Commerce. 6 (2), 26-38. 
Hasibuan, Malayu S.P. (2014). Manajemen: Dasar, Pengertian, danMasalah (EdisiRevisi). Jakarta: PT. BumiAksara.

Husein Umar. (2011). Metode Penelitian untuk Skripsi dan Tesis Bisnis. Jakarta: Rajawali Pers.

Kurniasih, Augustina \& Heliantono. (2016). "The Intellectual Capital of State-Owned Banks and the Influence of Organizational Performance". Scientific Journals of Management. VI (2), 195-212.

Mangkunegara, AA. Prabu. (2013). Evaluasi Kinerja Sumber Daya Manusia. Bandung: PT. RefikaAditama.

Mathis, R.L dan Jackson, (2011). Human Resource Management, Salemba Empat, Jakarta. Meldona. (2009). Manajemen Sumber Daya Manusia Perspektif Integratif. UIN Malang Press. Malang.

Moeheriono. (2012). Berbasis Kompetensi. Raja Grafindo Persada. Jakarta

Mondy, R. Wayne, (2010). Human Resource Management Eleventh. Edition: New Jersey: Prentice Hall.

Noe, Raymond A, Hollenback, John R, Gehart, Barry \& Wright, Patrick R. (2014). Manajemen Sumber Daya Manusia: Mencapai Keunggulan Bersaing. Jakarta: Salemba Empat, Edisi 6-Buku 1.

Rivai, Veithzal, (2008). Manajemen Sumber Daya Manusia Untuk Perusahaan dari Teori Ke Praktik. Jakarta: Raja Grafindo Perkasa.

Sedarmayanti. (2011). Sumber Daya Manusia dan Produktivitas Kerja. Bandung, PenerbitMandarMaju.

Simamora, Henry. (2010). Manajemen Sumber Daya Manusia. Edisi 3. STIE YKPN; Jogyakarta

Sinambela, Lijan Poltak. (2012). Manajemen Sumber Daya Manusia. Jakarta: PT BumiAksara.

Siagian, Sondang. (2014). Manajemen Sumber Daya Manusia. Cet 16. Jakarta: BumiAksara.

Stoner. (2013). PengantarBisnis. Grahallmu. Yogyakarta.

Sugiyono. (2015). Metode Penelitian Kuantitatif Kualitatif dan $R \&$ D.Bandung: Alfabeta.

Sunyoto, Danang. (2015). Penelitian Sumber Daya Manusia. Cetakan Pertama. Yogyakarta: CAPS (Center of Academic Publishing Service).

Sutrisno, Hadi, (2010). Metodelogi Penelitian Bisnis, Alfabeta Bandung.

Wibowo Tri, (2012). Manajemen Kinerja, Jakarta: PT Raja GrafindoPersada.

Wirawan. (2015). Evaluasi Kinerja Sumber Daya Manusia: TeoriAplikasidanPenelitian. Jakarta: Salemba Empat.

Veithzal, Rivai, (2008). Manajemen Sumber Daya Manusia untuk Perusahaan. PT. RajaGrafindo Persada: Jakarta.

Billy, Renaldo Potale. (2016). Pengaruh Rekrutment Dan Seleksi Terhadap Kinerja Karyawan Pada PT. Bank Sulut GO. JURNAL BERKALA ILMIAH EFISIENSI, 2016 - ejournal.unsrat.ac.id

Geeta, Kumari, dkk (2010). "Recruitment and Selection Process: a Case Study of Hindustan Coca-Cola Beverage Pvt. Ltd". International Jurnal of Innovation, Management and Technology, 1 (4), October 2010-ISSN: 2010-0248

Helena, Joan Komaling. (2016). Pengaruh Rekrutmen, Motivasi dan Lingkungan Kerja Terhadap Kinerja Pegawai (Study Kasus PT. Bank Rakyat Indonesia, TBK Cabang Manado. Sulawesi Utara 
Joe, O. Okwaba, dkk (2015). "The Impact of Recuitment and Selection Criteria on Organization Performance”. Journal of Human Resources Management, 3 (2), 22-23

Nindrijo Sunu Pambagio, Hamidah Nayati Utami, Gunawan Eko N. (2013). "Pengaruh Proses Rekrutmen, Proses Seleksi dan Kompetensi Karyawan Terhadap Kinerja Karyawan pada Karyawan Bagian Keuangan Tata Usaha dan Keuangan PG Kebon Agung Malang”. Jurnal Penelitian: Jurnal Ilmu Administrasi \& Organisasi

Nurjanah, Safitri, dkk. (2013). Analisa Pengaruh Proses Rekrutmen dan Seleksi Terhadap Kinerja Karyawan, Study kasus PT SIIX Electronics Indonesia.

Ombui Kephal, dkk (2012). "The Influence of "The Influence of Recruitment and Selection on the Performance of Employees in Research Institute in Kenya". International Journal of Science and Research (IJSR)-ISSN (Online): 2319-7064Impact Factor, 3 (3), 5-8.

EdyPranoto, dkk (2016). "Pengaruh Rekrutmen, Stress Kerjadan Pemberian Insentif Terhadap Produktivitas Kerja dengan Komitmen Organisasi sebagai Variabel Intervening Pada PT. Ungaran Sari Garment Unit III Congol Karangjati”. Journal of Management.

Setiani, Baiq. (2013). "Kajian Sumber Daya Manusia dalam Proses Rekrutmen Tenaga Kerja di Perusahaan”. Jurnal Ilmiah, 1 (1) 1-7.

Soedjono. (2005). "Pengaruh Budaya Organisasi Terhadap Kinerja Organisasi". Jurnal Manajemen \& Kewirausahaan, 7 (1) Universitas Kristen Petra.

Soelton, Mochamad and Oktapriatna, Neval, (2018). "How Complaining Behaviors Effect on Performance in Government Industries?". International Journal of Saudi Journal of Business and Management Studies (SJBMS). 3 (6), 623-628.

Soelton, Mochamad and Mahdalena, Lia, (2018). "Toward the Best Model in Recruiting Security Staffs at Outsourcing Industries". Research Journal of Finance and Accounting (RJFA). 9 (9), 26-32.

Soelton, Mochamad and Rakasidhi, Jaya, (2018). "How to Implementation Organization Citizenship Behaviors with performance on Accident insurance service". European Journal of Business and Management (EJBM). 10 (15), 10-16.

Sudham setti Naveen \&D.N.M Raju. (2014). "A study on Recruitment and Selection Process to Three Industries, Cement Industry, Electronics Industry, Sugar Industry In Krishna DtAp, India. Journal of Business and Management (IOSR-JBM) e-ISSN: 2278-487X, p-ISSN: 2319-7668. 15 (5), Jan 60-67

Yulasmi. (2016). "Pengaruh Rekrutmen, Seleksi Dan Penempatan Terhadap Kinerja Karyawan. Padang", MAJALAH ILMIAH UPI YPTK, Vol-23, No 1(2016). 